\title{
Butyrylcholinesterase and diabetes mellitus in the CHE2 C5- and CHE2 C5+ phenotypes
}

\author{
Butirilcolinesterase e diabetes melito nos \\ fenótipos CHE2 C5- e CHE2 C5+
}

Mauro M. Cwiertnia', Vânia M. Alcântara', Rosângela R. Réa², Ana Cristina R. A. Faria², Geraldo Picheth', Marileia Scartezini', Lorena E. Graef', Marciane Welter'

1 Departamento de Patologia Médica, Universidade Federal do Paraná (UFPR), Curitiba, PR, Brasil ${ }^{2}$ Serviço de Endocrinologia e Metabologia do Paraná, Departamento de Clínica Médica, UFPR, Curitiba, PR, Brasil
Correspondence to: Rosângela R. Réa Serviço de Endocrinologia, Universidade Federal do Paraná Rua Agostinho Leão Junior, 285 80030-110 - Curitiba, PR, Brasil rosangelarea@uol.com.br

Received on Apr/22/2009 Accepted on Aug/1/2009

\begin{abstract}
Objective: To investigate the relationship between butyrylcholinesterase ( $\mathrm{BChE}$ ) activities (total and band specific) and diabetes mellitus. Subjects and methods: $B C h E$ activities (BChEA, $A C_{45^{\prime}}$ $\mathrm{AC}_{\mathrm{OF}}$ and $\mathrm{RC}_{5}$ ) were analyzed in 101 type 1 (DM1) and in 145 type 2 (DM2) diabetic patients, in relation to phenotype, weight and incidence of metabolic syndrome (MS) in these patients. The $\mathrm{C}_{45}$ and $\mathrm{C}_{5}$ complex were separated from other molecular forms $\left(\mathrm{C}_{\mathrm{OF}}\right)$ using an acid agar gel. Results: The $B C h E$ activity (BChEA) and the absolute activities of $\mathrm{C}_{45}\left(\mathrm{AC}_{4 / 5}\right)$ and $\mathrm{C}_{\mathrm{OF}}\left(\mathrm{AC}_{\mathrm{OF}}\right)$ showed a high positive correlation coefficient to weight in the $\mathrm{CHE} 2 \mathrm{C5}$ - group, while the relative activity of $\mathrm{C}_{5}$ complex $\left(\mathrm{RC}_{5}\right)$ showed a negative correlation to weight. Conclusions: The present study suggests that the positive correlation of the $\mathrm{BChE}$ activities to diabetes mellitus and to insulin resistance may depend on the CHE2 locus variability. High values of BChE activities were associated with insulin resistance only in $\mathrm{CHE} 2 \mathrm{C} 5$ - diabetic patients, while in $\mathrm{CHE} 2 \mathrm{C} 5+$ diabetic patients, the presence of $\mathrm{C}_{5}$ complex, especially in a relatively high proportion, leads to less fat storage and better protection against metabolic syndrome. Arq Bras Endocrinol Metab. 2010;54(1):60-7

Keywords

$\mathrm{BCHE}$ and $\mathrm{CHE2}$ loci; $\mathrm{C}_{4 / 5}$ and $\mathrm{C}_{5}$ complexes; obesity, insulin resistance; metabolic syndrome; serum cholinesterase

RESUMO

Objetivo: Investigar a associação entre as atividades (total e banda específica) da butirilcolinesterase (BChE) e diabetes melito. Sujeitos e métodos: As atividades da $B C h E\left(B C h E A, A C_{455^{5}}, C_{0 F}\right.$ e $\mathrm{RC}_{5}$ ) foram analisadas em 101 pacientes diabéticos do tipo 1 (DM1) e 145 do tipo 2 (DM2) em relação aos fenótipos, ao peso e à incidência da síndrome metabólica. Os complexos $\mathrm{C}_{4 / 5}$ e $\mathrm{C}_{5}$ foram separados das outras formas moleculares $\left(\mathrm{C}_{\mathrm{OF}}\right)$, usando gel de ágar ácido. Resultados: $A$ atividade da $\mathrm{BChE}$ (BChEA) e as atividades absolutas de $\mathrm{C}_{45}\left(\mathrm{AC}_{4 / 5}\right)$ e de $\mathrm{C}_{\mathrm{OF}}\left(\mathrm{AC}_{\mathrm{OF}}\right)$ mostraram altos coeficientes de correlações positivos com peso no grupo de $\mathrm{CHE} 2 \mathrm{C5}$-, enquanto a atividade relativa do complexo $\mathrm{C}_{5}\left(\mathrm{RC}_{5}\right)$ mostrou correlação negativa com o peso. Conclusões: 0 presente estudo sugere que as correlações positivas das atividades da BChE com diabetes melito e com a resistência à insulina podem depender da variabilidade do loco CHE2. Altos valores nas atividades da $\mathrm{BChE}$ estão associados com a resistência à insulina somente nos pacientes diabéticos $\mathrm{CHE} 2 \mathrm{C5}$-, enquanto nos pacientes diabéticos $\mathrm{CHE} 2 \mathrm{C5}$ + a presença do complexo $\mathrm{C}_{5^{\prime}}$ especialmente em alta proporção relativa, leva a um menor estoque de gordura e à maior proteção contra a síndrome metabólica. Arq Bras Endocrinol Metab. 2010;54(1):60-7
\end{abstract}

Descritores

Locos BCHE e CHE2; complexos $\mathrm{C}_{4 / 5}$ e $\mathrm{C}_{5}$; obesidade, resistência à insulina; síndrome metabólica; colinesterase do soro

\section{INTRODUCTION}

$\mathrm{H}$ uman butyrylcholinesterase ( $\mathrm{BChE}$ ) is codified by the $B C H E$ locus that presents a few alleles with relatively high frequencies and a large number of rare alleles. Among phenotypes with differential response to inhibitors, BCHE U, BCHE UA and BCHE UF are the 
most common ones. In serum, one of the several molecular forms of $\mathrm{BChE}$, the $\mathrm{C}_{5}$ complex, is formed by association of $\mathrm{BChE}$ molecules with a still-unidentified protein, which is codified by the CHE2 locus (1). The presence of $\mathrm{C}_{5}$ (constituting about $10 \%$ of the EuroBrazilian population) characterizes the CHE2 C5+ phenotype (2), and the absence of this complex characterizes the CHE2 C5- phenotype. Sera from CHE2 C5+ individuals showed an approximate 30\% increase in mean BChE activity (BChEA) when compared with CHE2 C5- sera (3). CHE2 C5+ phenotype individuals showed lower mean body weight values (2) and lower mean body mass index (BMI) values (4) than noted in the CHE2 C5- phenotype.

In acid agar gel electrophoresis ( $\mathrm{pH} 6.2$ to 6.7), the $\mathrm{C}_{5}$ complex migrates to the positive pole, while all other $\mathrm{BChE}$ molecular forms $\left(\mathrm{C}_{\mathrm{OF}}\right)$ migrate toward the negative pole. All individuals (5) have another $\mathrm{BChE}$ complex $\left(\mathrm{C}_{4 / 5}\right)$ with the same mobility as $\mathrm{C}_{\mathrm{OF}}$ in acid agar gel $(\mathrm{pH}$ 6.2 to 6.7) electrophoresis, and with the same migration to the positive pole as $\mathrm{C}_{5}$, when the $\mathrm{pH}$ of the agar gel is $5.3(5)$.

The physiological function of $\mathrm{BChE}$ is still unknown, but positive correlations were found between BChEA and diabetes mellitus (DM) (6,7); triglycerides (TG) (7-9); total cholesterol (TC) $(7,10)$; apolipoprotein B (ApoB) $(7,9)$; adult body weight $(2,11)$ and BMI $(3,4)$. In light of some of these correlations, Kutty and cols. (12) proposed the use of BChEA as a complementary risk factor for coronary artery disease $(\mathrm{CAD})$, and also suggested the relationship of BChEA to metabolic syndrome (MS) (13).

The term diabetes mellitus comprises a group of metabolic disorders characterized by hyperglycemia due to defects in insulin secretion and/or in its action upon the organism. DM is classified into two main groups: type 1 (DMl), characterized by pancreas $\beta$-cell destruction due to autoimmune or idiopathic causes, resulting in insufficient insulin secretion; and type 2 (DM2), characterized by a resistance to insulin action and an inadequate compensatory insulin secretory response (14).

Coronary artery disease (CAD) is a known feature of complications in the prognosis of DM2 patients (15), and a high level of visceral fat is one of the main factors related to glucose intolerance and development of CAD (16), contributing to the sum of risk factors for DM onset (17) and to the deterioration of the lipid profile (18). Obesity in young adults has a positive correlation to development of DM (19). Other prognostic features for diabetes include high blood pressure, hyperinsulinemia and dislipidemia, with low serum levels of high density lipoprotein-cholesterol (HDL-C) and high levels of triglycerides (TG) (20).

Abbott and cols. (2l), studying the relationship between BChEA and hypertriglyceridemia in DMl and DM2 patients and in patients with impaired glucose tolerance, found a positive correlation between BChEA and the logarithm of fasting TG serum levels, and that BChEA also positively correlates to insulin resistance in DM2 patients. They concluded that BChE may play a role in the development of hypertriglyceridemia in DM, associated with the resistance to or deficiency of insulin.

Typical dislipoproteinemia in DM2 patients is characterized by the presence of high levels of very low density lipoprotein-cholesterol (VLDL-C), small and dense low density lipoprotein (LDL), and HDL-C below desirable levels (22). The small dense LDL is highly atherogenic due to its high susceptibility to modifications by oxidation (23). Frohlich and Dobiasova (24) demonstrated that the TG/HDL-C ratio, and especially its logarithm (logTG/HDL-C), have a high correlation to LDL particle size and can therefore be used as a risk predictor for CAD.

This is the first study that separately analyzes the activity of $\mathrm{C}_{4 / 5}$ and $\mathrm{C}_{5}$ complexes of $\mathrm{BChE}$ in diabetic patients (DM1 and DM2), and the BChE activities in CHE2 C5+ and CHE2 C5- phenotypes.

\section{SUBJECTS AND METHODS}

\section{Subjects}

Plasma samples were collected with EDTA after at least 12 hours of fasting. DMl and DM2 patients were selected from the Diabetes Outpatient Clinic of Universidade Federal do Paraná, in Curitiba (Southern Brazil). The DM group included $101 \mathrm{DMl}$ patients, aged 24.3 \pm 7.3 years $(61.0 \%$ female, $72 \%$ Euro-Brazilian and $28 \%$ Afro-Brazilian) and 145 DM2 patients, aged $55.0 \pm$ 11.4 years (66.2\% female, 64\% Euro-Brazilian and 36\% Afro-Brazilian). Controls were obtained from a Curitiba population sample (blood donors, university staff and students) consisting of 186 individuals, aged $37.8 \pm 15.6$ years (59.1\% female, incomplete data on ethnic origin).

The initial sample comprised of $104 \mathrm{DMl}$ patients and 147 DM2 patients; however, $4 \mathrm{DMl}$ and $2 \mathrm{DM} 2$ were excluded from the sample due to the presence of abnormal phenotypes with low BChEA values. Out of the 145 DM2 patients, 39 were taking hypoglycemic 
medications (HM); 25 taking HM and Insulin (I), 22 taking HM and sulfa (S), 34 only insulin, 14 only sulfa, 10 both insulin and sulfa, and 1 taking HM with insulin and sulfa. According to Abbott and cols. (21), medication type should not interfere with BChE activity.

This research was approved by the Ethics Committee of the University Hospital, of the institution (protocol $\left.\mathrm{n}^{\circ} 327.037 / 2001-04\right)$.

\section{Laboratory methods}

Glucose (GLC) was quantified by glucose-hexoquinase (Merck Mega method); TG and TC were quantified by colorimetric enzymatic reactions (Merck, SMT); and HDL-C by homogeneous direct method (Roche). $\mathrm{HbA}_{\mathrm{lc}}$ and apolipoprotein B (Apo B) were determined by high performance liquid chromatography (BioRad) and by turbidimetry (Roche), respectively. Insulin (I) was determined by radioimmunoassay (Diagnostics Products Corporation, Los Angeles, CA, USA). All these analyses were performed on the day of sample collection.

Non-hemolized serum samples were stored at $-20^{\circ} \mathrm{C}$. BChE activities and the phenotypes of the $B C H E$ and CHE2 loci were verified within eight days of storage. BChEA was measured by the colorimetric propionylthiocholine-DTNB reaction at $25^{\circ} \mathrm{C}$, using the method described by Dietz and cols. (25), as modified by Evans and Wroe (26). The phenotypes of the CHE2 locus were identified by acid agar gel electrophoresis ( $\mathrm{pH}$ 6.5), followed by a staining process using alphanaphthyl acetate as substrate and fast red TR salt, in a modification of the Van Ros and Vervoort method (27). This methodology allows band-by-band separation of $\mathrm{C}_{5}$ from all the other $\mathrm{BChE}$ forms $\left(\mathrm{C}_{\mathrm{OF}}\right)$. In the case of the CHE2 C5- phenotype, the $\mathrm{C}_{4 / 5}$ band is separated from the $\mathrm{C}_{\mathrm{OF}}$ band by a modification of this methodology (5) using agar gel at $\mathrm{pH} 5.3$, in a 2.5 hour run (Figure 1). Because the intensities of these bands modify with storage, analysis was performed four months after sample collection, the period required for their stabilization. The relative activities (\%) of $\mathrm{C}_{4 / 5}$ and $\mathrm{C}_{5}$ bands $\left(\mathrm{RC}_{4 / 5}\right.$ and $\mathrm{RC}_{5}$, respectively) were measured after gel scanning with the Kodak Digital (28) Corel Photo Paint 9 (1999), and the bands quantified by the Kodak 1D (29) Image Analysis Software for Windows (1992-2000). The samples were examined in duplicate and whenever the results were not reproducible, new trials were performed until three results were in agreement. The absolute activity $\left(\mathrm{AC}_{4 / 5}\right)$ of the $\mathrm{C}_{4 / 5}$ bands was then calculated [relative activity of these bands $\left(\mathrm{RC}_{4 / 5}\right)$ multiplied by their total activity (BChEA)].

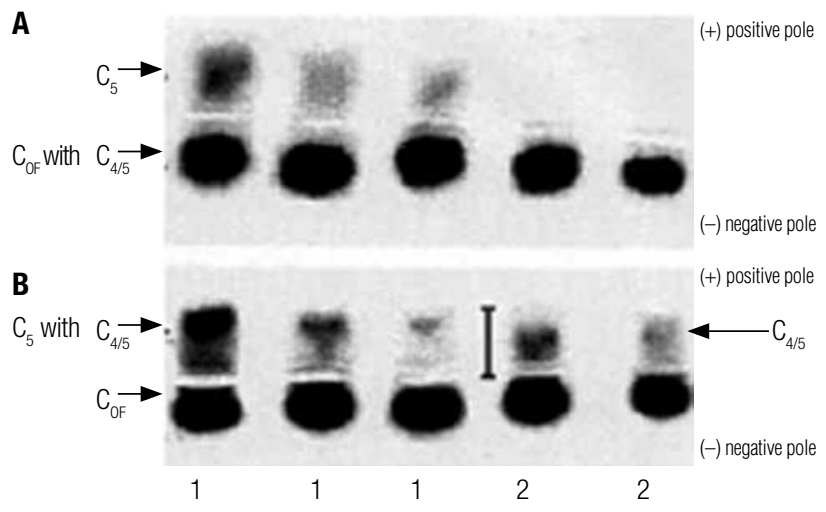

Figure 1. Fragments of two electrophoreses in agar gel of $\mathrm{pH} 6.5$ (A) and pH 5.3 (B). Representative migration of CHE2 C5+ (lines 1) and of CHE2 C5- (lines 2).

The diagnosis of DMl was assigned when the fasting glucose concentration exceeded $126 \mathrm{mg} / \mathrm{dL}$ (or was previously $140 \mathrm{mg} / \mathrm{dL}$ ) and/or random plasma glucose levels exceeded $200 \mathrm{mg} / \mathrm{dL}$ on more than one occasion, with or without overt symptoms or signs of diabetes.

HOMA-IR (31) is a mathematical model that predicts insulin resistance (IR) and/or secretion of insulin by pancreatic $\beta$-cells by measuring insulin and fasting blood glucose: HOMA-IR = Glucose $(\mathrm{mMol}) \mathrm{x}$ Insulin $(\mu \mathrm{U} / \mathrm{mL}) / 22.5$.

\section{Statistical analyses}

Data analyses were performed with the Statistica software (30) that calculated Student's $t$-test for independent means comparisons, $\chi^{2}$ tests, and stepwise multiple regression analyses.

The analyzed variables in diabetic patients were: BChEA, sex, age, ethnic origin, systolic pressure (SP), diastolic pressure (DP), body mass index (BMI), glucose (GLC), HbA, Apo B, TC, TG, logTG, HDL-C, I, phenotypes of the CHE2 locus (PCL) and diabetes type (DT).

\section{RESULTS AND DISCUSSION}

Previous studies $(4,32)$ have shown the influence of CHE2 locus in BChEA. This study has taken this inquiry to the next level of isolating influencing factors by separately analyzing the CHE2 C5- and CHE2 C5+ phenotypes in both diabetic and in non-diabetic controls.

The incidence of the CHE2 C5+ phenotype in DMl $(13.5 \% \pm 3.4 \%)$ and in DM2 $(13.6 \% \pm 2.8 \%)$ did 
not differ significantly from the incidence found in a Curitiba blood donor sample in an earlier study $(2):(\mathrm{N}$ $=2,541 ; 10.50 \% \pm 0.62 \%) ;\left(\chi^{2}=0.92, \mathrm{p}>0.30\right.$ and $\chi^{2}$ $=1.40, \mathrm{p}>0.20$; respectively $)$.

Table 1 shows mean comparisons found by $t$-test between DMl and DM2 patients with the CHE2 C5phenotype. Most of the mean values are significantly higher in DM2 than in DMl, except for height, $\mathrm{HbA}_{1 \mathrm{c}}$, GLC, and HDL-C, all of which presented higher values in DMl. These findings seem to reflect the metabolic alterations characteristic of DM2, with higher means for BMI, SP, DP, ApoB, TC, TG, $\log$ TG, $\log$ TG/HDL and BChE activities. The elevation of $\log \mathrm{TG} / \mathrm{HDL}$ in these patients indicates that they have a higher proportion of small and dense LDL particles (24) and, therefore, a higher risk for coronary artery disease (CAD).

Table 2 shows the $t$-test results for the mean values of age and BChE activities in the DMl and DM2 groups with the CHE2 C5- phenotype, compared to controls, and paired by sex and age. $\mathrm{DMl}$ presented higher significant mean values for $\mathrm{RC}_{4 / 5}$ and $\mathrm{AC}_{4 / 5}$ but not for $\mathrm{BChEA}$ and $\mathrm{AC}_{\mathrm{OF}}$. Analyses of other variables (not shown in the table) presented significant higher mean values for BMI, GLC, TC, Apo B, and $\mathrm{HbAl}$ in $\mathrm{DMl}$ when compared with the controls, but not for the values for TG, $\log \mathrm{TG}, \mathrm{HDL}-\mathrm{C}$ and $\log \mathrm{TG} /$ HDL-C. However, the DM2 subjects presented higher values for a majority of the analyzed variables, except for height, $\mathrm{HDL}-\mathrm{C}$ and $\mathrm{AC}_{\mathrm{OF}}$. The pairing procedure was used because males and older individuals presented higher mean values for $\operatorname{BChEA}(4,7,9,33,34), \mathrm{AC}_{4 / 5}$ $(4,34)$ and $\mathrm{AC}_{\mathrm{OF}}(4)$, when compared to females and younger individuals with $\mathrm{CHE} 2 \mathrm{C} 5$ - phenotype.

After logistic multiple-regression analysis (Table 3), BChEA and $\mathrm{AC}_{\mathrm{OF}}$ in the DMl CHE2 C5- sample presented statistically significant standardized regression coefficients with Apo B and $\log$ TG (or TG). AC 4 .5 correlated only with Apo B. In DM2, BChE activities showed significant correlation with Apo B, logTG and HOMA-IR. When the DMl and DM2 groups were analyzed together, $\mathrm{BChEA}$ and $\mathrm{AC}_{\mathrm{OF}}$ presented positive and significant correlation with Apo B, $\log \mathrm{TG}$ (or TG), HOMA-IR and DT, and $\mathrm{AC}_{4 / 5}$ only correlated significantly with Apo B and $\log \mathrm{TG}$. The $\mathrm{AC}_{4 / 5}$ variability was better understood in DM2 (30\%), while the BChEA and $\mathrm{AC}_{\mathrm{OF}}$ variances were better understood in $\mathrm{DMl}$ (40\% and $33 \%$, respectively), notably in the DMl and DM2 samples analyzed together $(44 \%)$.
Table 1. Characteristics of DM1 and DM2 patients with CHE2 C5- phenotype

\begin{tabular}{|c|c|c|c|}
\hline Variables & DM1 (n) & DM2 (n) & $t(p)$ \\
\hline Age (years) & $24.63 \pm 7.52(86)$ & $54.44 \pm 11.65(125)$ & $21.0(<0.0001)$ \\
\hline Height (m) & $1.63 \pm 0.09(86)$ & $1.61 \pm 0.09(125)$ & $2.0(<0.05)$ \\
\hline BMI $\left(\mathrm{kg} / \mathrm{m}^{2}\right)$ & $23.32 \pm 3.39(86)$ & $30.04 \pm 5.34(125)$ & $10.3(<0.0001)$ \\
\hline $\mathrm{SP}(\mathrm{mmHg})$ & $116.48 \pm 13.18(84)$ & $141.27 \pm 18.30(122)$ & $10.7(<0.0001)$ \\
\hline $\mathrm{DP}(\mathrm{mmHg})$ & $72.68 \pm 9.23(84)$ & $87.77 \pm 10.71$ (122) & $10.5(<0.0001)$ \\
\hline $\mathrm{HbA}_{1 \mathrm{c}}(\%)$ & $10.04 \pm 2.38(86)$ & $8.61 \pm 2.07(124)$ & $4.6(<0.0001)$ \\
\hline $\mathrm{GLC}(\mathrm{mg} / \mathrm{dL})$ & $216.04 \pm 116.22(83)$ & $182.78 \pm 72.38(125)$ & $2.5(<0.05)$ \\
\hline$A p o B(m g / d L)$ & $88.88 \pm 26.33(86)$ & $116.84 \pm 29.66(125)$ & $7.0(<0.0001)$ \\
\hline $\mathrm{TC}(\mathrm{mg} / \mathrm{dL})$ & $187.80 \pm 45.91(85)$ & $223.92 \pm 50.26(124)$ & $5.3(<0.0001)$ \\
\hline $\mathrm{TG}(\mathrm{mg} / \mathrm{dL})$ & $98.69 \pm 72.04(85)$ & $184.56 \pm 146.28(124)$ & $5.1(<0.0001)$ \\
\hline $\log G$ & $1.92 \pm 0.25(85)$ & $2.17 \pm 0.27(124)$ & $7.1(<0.0001)$ \\
\hline $\mathrm{HDL}-\mathrm{C}(\mathrm{mg} / \mathrm{dL})$ & $50.03 \pm 11.35(86)$ & $44.60 \pm 12.10(121)$ & $3.3(<0.01)$ \\
\hline $\mathrm{I}(\mu \mathrm{Ul} / \mathrm{mL})$ & $25.68 \pm 27.60(84)$ & $19.48 \pm 17.71$ (122) & $2.0(=0.05)$ \\
\hline $\log T G / H D L$ & $0.04 \pm 0.01(85)$ & $0.05 \pm 0.02(121)$ & $5.6(<0.0001)$ \\
\hline HOMA-IR & $9.86 \pm 7.48(81)$ & $8.63 \pm 7.93$ (122) & $1.1(>0.20)$ \\
\hline \multicolumn{4}{|c|}{ BChEA activities } \\
\hline BChEA (kU/L) & $5.05 \pm 0.92(86)$ & $6.10 \pm 1.34(125)$ & $6.3(<0.0001)$ \\
\hline $\mathrm{RC}_{4 / 5}(\%)$ & $17.85 \pm 5.70(86)$ & $19.60 \pm 7.07(125)$ & $1.9(>0.05)$ \\
\hline $\mathrm{AC}_{4 / 5}(\mathrm{kU} / \mathrm{L})$ & $0.93 \pm 0.39(86)$ & $1.23 \pm 0.61(125)$ & $4.0(<0.0001)$ \\
\hline $\mathrm{AC}_{\mathrm{OF}}(\mathrm{kU} / \mathrm{L})$ & $4.13 \pm 0.71(86)$ & $4.87 \pm 1.02(125)$ & $6.0(<0.0001)$ \\
\hline
\end{tabular}

Mean \pm standard deviation, $\mathrm{t}$-test( $\mathrm{t}), \mathrm{p}$-value $(\mathrm{p})$; sample size $(\mathrm{n})$.

BMl: body mass index, SP: systolic pressure, DP: diastolic pressure, GLC: glucose, TC: total cholesterol, TG: triglycerides, logTG: logarithm of TG, I: insulin.

Table 2. BChE activity in diabetic patients (DM1 and DM2) with CHE2 C5- phenotype

\begin{tabular}{|c|c|c|c|}
\hline Variables & DM1 $(n=78)$ & Controls $(n=78)$ & $t(p)$ \\
\hline Age (years) & $24.83 \pm 7.58$ & $24.91 \pm 6.92$ & $0.1(>0.90)$ \\
\hline BChEA (kU/L) & $5.03 \pm 0.90$ & $4.88 \pm 0.92$ & $1.6(>0.10)$ \\
\hline $\mathrm{RC}_{4 / 5}(\%)$ & $18.18 \pm 5.51$ & $16.42 \pm 4.44$ & $2.2(<0.05)$ \\
\hline $\mathrm{AC}_{4 / 5}(\mathrm{kU} / \mathrm{L})$ & $0.94 \pm 0.39$ & $0.80 \pm 0.29$ & $2.5(<0.05)$ \\
\hline $\mathrm{AC}_{\mathrm{OF}}(\mathrm{kU} / \mathrm{L})$ & $4.11 \pm 0.66$ & $4.00 \pm 0.75$ & $0.9(>0.30)$ \\
\hline Variables & DM2 $(n=80)$ & Controls $(n=80)$ & $t(p)$ \\
\hline Age (years) & $50.61 \pm 11.38$ & $47.59 \pm 3.03$ & $1.6(>0.10)$ \\
\hline BChEA (kU/L) & $6.09 \pm 1.25$ & $5.47 \pm 0.98$ & $3.5(<0.001)$ \\
\hline $\mathrm{RC}_{4 / 5}(\%)$ & $20.39 \pm 7.05^{\star}$ & $14.71 \pm 4.87$ & $5.9(<0.0001)$ \\
\hline $\mathrm{AC}_{4 / 5}(\mathrm{kU} / \mathrm{L})$ & $1.28 \pm 0.62^{*}$ & $0.83 \pm 0.33$ & $5.6(<0.0001)$ \\
\hline $\mathrm{AC}_{\mathrm{OF}}(\mathrm{kU} / \mathrm{L})$ & $4.81 \pm 0.90^{\star}$ & $4.71 \pm 0.79$ & $0.7(>0.40)$ \\
\hline
\end{tabular}

Mean \pm standard deviation, t-test $(t), p$-value $(p)$, sample size $(n),{ }^{*} n=77$.

BChEA correlation with Apo B (7,9) and TG (7-9) has been noted in other studies. In the CHE2 C5- obese group sample (4), the correlation of $\mathrm{AC}_{4 / 5}$ and $\mathrm{AC}_{\mathrm{OF}}$ with TC was also observed. Apo B and TC comprise part of the low density lipoprotein cholesterol (LDL-C) and have high positive correlation. 
Table 3. Stepwise multiple regression analysis in DM1 and DM2 with CHE2 C5- phenotype considering BChE activities as a dependent variable

\begin{tabular}{|c|c|c|c|c|c|}
\hline \multicolumn{6}{|l|}{ D.V. } \\
\hline DM1 (n) & Apo B & $\log T G$ & HOMA-IR & $\mathbf{R}^{2}$ & \\
\hline BChEA (85) & $+0.45(p<0.001)$ & $+0.23(p<0.05)^{\&}$ & NS & 0.40 & \\
\hline $\mathrm{AC}_{4 / 5}(86)$ & $+0.48(p<0.0001)$ & NS & NS & 0.23 & \\
\hline $\mathrm{AC}_{0 \mathrm{~F}}(85)$ & $+0.38(p<0.01)$ & $+0.24(p<0.05)$ & NS & 0.33 & \\
\hline DM2 (n) & & & & $\mathbf{R}^{2}$ & \\
\hline BChEA (121) & $+0.34(p<0.001)$ & $+0.23(p<0.01)$ & $+0.21(p<0.01)$ & 0.30 & \\
\hline $\mathrm{AC}_{4 / 5}(121)$ & $+0.33(p<0.001)$ & $+0.23(p<0.01)$ & $+0.21(p<0.01)$ & 0.30 & \\
\hline $\mathrm{AC}_{\mathrm{OF}}(124)$ & $+0.30(p<0.001)$ & $+0.20(p<0.05)$ & $+0.26(p<0.01)$ & 0.28 & \\
\hline DM1 and DM2 (n) & & & & DT & $\mathbf{R}^{2}$ \\
\hline BChEA (201) & $+0.36(p<0.0001)$ & $+0.21(p<0.01)$ & $+0.20(p<0.001)$ & $+0.18(p<0.01)$ & 0.44 \\
\hline $\mathrm{AC}_{4 / 5}(209)$ & $+0.36(p<0.0001)$ & $+0.16(p<0.05)^{\&}$ & NS & NS & 0.21 \\
\hline $\mathrm{AC}_{\mathrm{OF}}(209)$ & $+0.33(p<0.0001)$ & $+0.20(p<0.01)$ & $+0.23(p<0.001)$ & $+0.17(p<0.01)$ & 0.44 \\
\hline
\end{tabular}

DV: dependent variable; $n$ : sample size; logTG: logarithm of triglycerides; DT: diabetes type; NS: non-significant result; \&: variable without logarithm.

The correlations of BChEA and $\mathrm{AC}_{\mathrm{OF}}$ with diabetes type (DT) indicate that these activity levels were greater in DM2 subjects than in DMl subjects. An earlier study (21) showed that the mean values of BChEA in DMl and DM2 were not significantly different. However, this result was not replicated in the present study. Of note, the previous study did not mention the proportion of women in its diabetic sample, nor how many women were taking oral contraceptives. One possible reason for the discrepancy in findings is that our DMl sample had a greater number of women than men, and $25 \%$ of those women used oral contraceptives. The negative correlation of BChEA with estradiol is supported by data showing a higher mean value for BChEA in men than in females during their fertile period, a difference that disappears after menopause (35). Decrease of total BChE activity was also reported during pregnancy, when an increased synthesis of estrogens occurs $(36,37)$.

Age and sex, despite not showing a correlation with BChEA in the diabetic samples, may, however, influence BChEA activity secondarily to the increase caused by dislipidemia. Groups DM1 and DM2 were both divided into four groups, by age and sex. Group 1 = women with median age under 23; Group 2 = men with median age under 23; Group 3 = women with median age over 23; and Group $4=$ men with median age over 23. Group 1 showed lower mean values for BChEA $(\mathrm{t}=3.6 ; \mathrm{p}<0.001), \mathrm{AC}_{4 / 5}$ $(\mathrm{t}=2.6 ; \mathrm{p}<0.01)$ and $\mathrm{AC}_{\mathrm{OF}}(\mathrm{t}=3.3 ; \mathrm{p}<0.001)$, when compared to Group 3. Group 1 also showed lower mean values for BChEA $(\mathrm{t}=2.1 ; \mathrm{p}<0.05)$ and $\mathrm{AC}_{4 / 5}(\mathrm{t}=2.4$; $\mathrm{p}<0.05)$, when compared to Group 4 .
It is known that DM2 has been positively correlated to obesity (38). Considering that obese CHE2 C5- subjects display similar metabolic alterations to CHE2 C5- DM2 subjects, the present data are in accordance with the studies that show higher mean values for $\mathrm{BChEA}, \mathrm{AC}_{4 / 5}$ and $\mathrm{AC}_{\mathrm{OF}}$ in obese subjects, when compared to a non-obese sample of the general population of Curitiba $(4,32,34)$.

In DM2, the HOMA-IR shows strong correlation with BChE activities. In DMl patients, the HOMA-IR frequency (greater than 2.71) did not differ from those of DM2 patients. Furthermore, the HOMA-IR mean values for DMl did not differ from those of the DM2 group (Table 1), and did not show correlation with BChE activities in the DMl group using logistic regression analyses. The HOMA-IR has been positively correlated to BMI (39).

Although obesity is a frequent feature of DM2, many DMl patients are prone to high BMI. Recent studies suggest that HOMA-IR is a common finding among this diabetic type, $(40,41)$ and that HOMA-IR correlates positively with BMI $(42,43)$.

Positive correlations of BChEA with body weight $(2,4,34)$, BMI $(4,34)$ and metabolic syndrome (MS) (13) have already been observed in the CHE2 C5- phenotype. Positive correlations of $\mathrm{BMI}(4,34)$ and MS (13) with $\mathrm{BChEA}, \mathrm{AC}_{4 / 5}$ and $\mathrm{AC}_{\mathrm{OF}}$ have also been reported.

The World Health Organization (WHO) defines "overweight" as a BMI equal to or more than 25 (44). Therefore, we split the total sample (DM1 and DM2) according to this value, in other words, non-overweight (BMI equal to or less than 25) and overweight (BMI greater than 25) with the results shown in table 4 . 
Table 4. BChE activity in diabetic patients (DM1 and DM2) with CHE2 C5- phenotype according to the bone mass index (BMI)

\begin{tabular}{lccc}
\hline Variables & $\begin{array}{c}\mathbf{B M I}<\mathbf{2 5} \\
(\mathbf{n}=\mathbf{8 8})\end{array}$ & $\begin{array}{c}\mathbf{B M I} \geq \mathbf{2 5} \\
(\mathbf{n}=\mathbf{1 2 5})\end{array}$ & $\mathbf{t}(\mathbf{p})$ \\
\hline Age $($ years $)$ & $32.66 \pm 16.14$ & $52.50 \pm 15.75$ & $7.4(<0.0001)$ \\
$\mathrm{BChEA}(\mathrm{kU} / \mathrm{L})$ & $5.20 \pm 0.94$ & $6.01 \pm 1.41$ & $4.7(<0.0001)$ \\
$\mathrm{RC}_{4 / 5}(\%)$ & $18.77 \pm 6.22$ & $18.97 \pm 6.86$ & $0.2(>0.80)$ \\
$\mathrm{AC}_{4 / 5}(\mathrm{kU} / \mathrm{L})$ & $1.00 \pm 0.44$ & $1.18 \pm 0.61$ & $2.3(<0.05)$ \\
$\mathrm{AC}_{\mathrm{OF}}(\mathrm{kU} / \mathrm{L})$ & $4.23 \pm 0.75$ & $4.83 \pm 1.05$ & $4.6(<0.0001)$ \\
\hline
\end{tabular}

Mean \pm standard deviation, sample size $(n), t$-test $(t)$, $p$-value $(p)$.

It was suggested in a previous study (21) that BChEA may have a role in the altered lipoprotein metabolism in hypertriglyceridemia associated with insulin insensitivity or insulin deficiency in diabetes mellitus. However, the results obtained in the present study support the findings of Iwasaki and cols. (45) which indicate that BChEA is associated with the parameters of adiposity, serum lipid profile and the degree of insulin resistance. This current study suggests that BCHEA activities were more frequently correlated to obesity and metabolic syndrome disorder than to just the $\beta$-cell dysfunction in the CHE2 C5- DMl group.

In patients with the CHE2 C5+ phenotype, no differences in the mean values of $\mathrm{BChEA}$ were observed when DMI and DM2 were compared (Table 5), other than the

Table 5. DM1 and DM2 patients with CHE2 C5+ phenotype

\begin{tabular}{|c|c|c|c|}
\hline Variables & DM1 (n) & DM2 (n) & $t(p)$ \\
\hline Age (years) & $22.36 \pm 5.21(14)$ & $58.35 \pm 8.99(20)$ & $13.4(<0.0001)$ \\
\hline Height (m) & $1.63 \pm 0.08(13)$ & $1.57 \pm 0.10(20)$ & $1.7(>0.05)$ \\
\hline BMI $\left(\mathrm{kg} / \mathrm{m}^{2}\right)$ & $23.10 \pm 3.74(13)$ & $30.75 \pm 4.72(20)$ & $4.9(<0.0001)$ \\
\hline SP (mmHg) & $122.31 \pm 16.91(13)$ & $144.00 \pm 18.47(20)$ & $3.4(<0.01)$ \\
\hline $\mathrm{DP}(\mathrm{mmHg})$ & $77.69 \pm 11.66(13)$ & $88.50 \pm 12.26(20)$ & $2.5(<0.05)$ \\
\hline $\mathrm{HbA}_{1 \mathrm{c}}(\%)$ & $9.20 \pm 2.37(14)$ & $8.75 \pm 1.99(20)$ & $0.6(>0.50)$ \\
\hline GLC (mg/dL) & $203.93 \pm 107.33(14)$ & $182.80 \pm 58.63(20)$ & $0.7(>0.40)$ \\
\hline Apo B (mg/dL) & $83.64 \pm 25.97(14)$ & $112.25 \pm 31.48(20)$ & $2.8(<0.01)$ \\
\hline $\mathrm{TC}(\mathrm{mg} / \mathrm{dL})$ & $169.14 \pm 33.62(14)$ & $217.65 \pm 57.01(20)$ & $2.8(<0.01)$ \\
\hline $\mathrm{TG}(\mathrm{mg} / \mathrm{dL})$ & $75.64 \pm 40.50(14)$ & $151.65 \pm 71.13(20)$ & $3.6(<0.01)$ \\
\hline $\log T G$ & $1.83 \pm 0.21(14)$ & $2.14 \pm 0.20(20)$ & $4.4(<0.001)$ \\
\hline $\mathrm{HDL}-\mathrm{C}(\mathrm{mg} / \mathrm{dL})$ & $50.00 \pm 16.11(14)$ & $46.40 \pm 11.06(20)$ & $0.8(>0.40)$ \\
\hline I ( $\mu \mathrm{Ul} / \mathrm{mL})$ & $23.06 \pm 23.45$ (14) & $19.42 \pm 8.86(20)$ & $0.6(>0.50)$ \\
\hline $\log \mathrm{TG} / \mathrm{HDL}$ & $0.04 \pm 0.02(14)$ & $0.05 \pm 0.01(20)$ & $1.6(>0.10)$ \\
\hline HOMA-IR & $9.15 \pm 6.84(14)$ & $8.75 \pm 4.87(20)$ & $0.2(>0.80)$ \\
\hline \multicolumn{4}{|c|}{ BChEA activities } \\
\hline BChEA (kU/L) & $6.75 \pm 1.01$ & $6.95 \pm 1.33$ & $0.5(>0.60)$ \\
\hline $\mathrm{RC}_{5}(\%)$ & $26.85 \pm 7.93$ & $18.71 \pm 8.23$ & $2.9(<0.01)$ \\
\hline
\end{tabular}

BMI: body mass index, WHR: waist-to-hip ratio, SP: systolic pressure, DP: diastolic pressure, GLC: glucose; TC: total cholesterol, TG: triglycerides, logTG: logarithm of TG.
DM2 group presenting higher mean values in a majority of the analyzed variables (except for height, $\mathrm{HbA}_{1 \mathrm{c}}$, GLC, and HDL-C). However, $\mathrm{RC}_{5}$ presented a significantly lower mean value in DM2 when compared with DMl subjects. When the mean values of the DMl and DM2 BChE activities were compared with those of the controls (Table 6), statistically significant differences were shown only in the $\mathrm{RC}_{5}$ of the $\mathrm{DM} 2$ group, with lower mean values than in the controls. Control subjects were not paired by sex and age, because it has not been demonstrated that the variables of sex and age alter BChEA in individuals with the CHE2 C5+phenotype (32).

Table 6. BChE activity in DM1 and DM2 patients with CHE2 C5+ phenotype

\begin{tabular}{|c|c|c|c|c|c|}
\hline & $\begin{array}{l}\text { Control } \\
(n=27)\end{array}$ & $\begin{array}{c}\text { DM1 } \\
(n=14)\end{array}$ & $t(p)$ & $\begin{array}{c}\text { DM2 } \\
(n=20)\end{array}$ & $t(p)$ \\
\hline $\begin{array}{l}\text { Age } \\
\text { (years) }\end{array}$ & $41.52 \pm 12.73$ & $22.36 \pm 5.21$ & $\begin{array}{c}5.4 \\
(<0.0001)\end{array}$ & $58.35 \pm 8.99$ & $\begin{array}{c}5.0 \\
(<0.0001)\end{array}$ \\
\hline $\begin{array}{l}\text { BChEA } \\
(\mathrm{kU} / \mathrm{L})\end{array}$ & $6.61 \pm 1.98$ & $6.75 \pm 1.01$ & $\begin{array}{c}0.2 \\
(>0.80)\end{array}$ & $6.95 \pm 1.33$ & $\begin{array}{c}0.7 \\
(>0.50)\end{array}$ \\
\hline $\begin{array}{l}\mathrm{RC}_{5} \\
(\%)\end{array}$ & $25.97 \pm 14.89$ & $26.86 \pm 7.93$ & $\begin{array}{c}0.3 \\
(>0.60)\end{array}$ & $18.71 \pm 8.23$ & $\begin{array}{c}1.9 \\
(=0.05)\end{array}$ \\
\hline
\end{tabular}

Mean \pm standard deviation, $\mathrm{t}$-test, sample size (n).

Considering that the CHE2 C5+ obese group also displays similar metabolic alterations as the CHE2 C5+ DM2 group, the present data concur with the studies that did not show higher mean values for BChEA but presented lower mean values for $\mathrm{RC}_{5}$ in obese subjects, when compared with non-obese subjects in a sample of the general population of Curitiba (32).

Table 7 shows the $t$-test results obtained after sample division by the median value $(22.9 \%)$ of $\mathrm{RC}_{5}$ (obtained from the $\mathrm{DMl}$ and control groups, whose averages did not differ significantly).

Table 7 includes only variables which presented mean values with significant differences. The BMI and TG variables showed lower mean values among the in-

Table 7. Bone mass index (BMI), triglycerides (TG) and in HDL-C according to the intensity of CHE2 C5+ activitiy

\begin{tabular}{|c|c|c|c|}
\hline & Faint $\mathrm{RC}_{5}(\mathrm{n})$ & Intense $\mathrm{RC}_{5}(\mathrm{n})$ & $t(p)$ \\
\hline $\mathrm{BMI}\left(\mathrm{kg} / \mathrm{m}^{2}\right)$ & $29.76 \pm 6.52(17)$ & $25.58 \pm 3.88(16)$ & $2.2(<0.05)$ \\
\hline $\mathrm{TG}(\mathrm{mg} / \mathrm{dL})$ & $126.94 \pm 66.32(32)$ & $98.21 \pm 46.94(29)$ & $1.9(=0.05)$ \\
\hline $\mathrm{HDL}-\mathrm{C}(\mathrm{mg} / \mathrm{dL})$ & $45.87 \pm 11.35(30)$ & $53.88 \pm 17.65(24)$ & $2.0(<0.05)$ \\
\hline \multicolumn{4}{|c|}{ BChEA activities } \\
\hline $\mathrm{BChEA}(\mathrm{kU} / \mathrm{L})$ & $6.19 \pm 1.65(32)$ & $7.37 \pm 1.26(29)$ & $3.1(<0.01)$ \\
\hline $\mathrm{RC}_{5}(\%)$ & $14.08 \pm 5.55(32)$ & $34.03 \pm 7.52(29)$ & $11.9(<0.0001)$ \\
\hline
\end{tabular}

Mean \pm standard deviation, $\mathrm{t}$-test, sample size $(\mathrm{n})$. 
tense CHE2 C5 + phenotype, and HDL-C presented a higher mean value in this phenotype. The correlation (r) of $\mathrm{RC}_{5}$ with BMI, HDL-C and TG are -0.5658 , +0.32537 and $-0,4098$ respectively. The negative correlation between $\mathrm{BMI}$ and $\mathrm{RC}_{5}$ has already been described in an obese sample (32).

The present study suggests that the positive correlations of BChE activities with diabetes mellitus and with insulin resistance may depend on the CHE2 locus variability. Our observation is that the high values of $\mathrm{BChE}$ activities were associated with insulin resistance only in diabetic patients with CHE2 C5- phenotype, yielding our hypothesis that the presence of $\mathrm{C}_{5}$ complex, and particularly in a relatively high proportion, contributes to less fat storage and more protection against Metabolic Syndrome.

Acknowledgements: Hoffmann-La Roche and Co., Rio de Janeiro, RJ, Brazil, donated the Ro2-0683 inhibitor. Produtos Roche Químicos e Farmacêuticos S.A. and Bio-Oxford Importação Ltda/Bio-Rad Latin America donated the Apo B and the $\mathrm{HbA}_{\mathrm{lc}}$ kits, respectively. Frischmann Ainsengart Laboratory performed these quantifications. This research was supported by fellowships from Conselho Nacional de Desenvolvimento Científico e Tecnológico $(\mathrm{CNPq})$ and by grants from $\mathrm{CNPq}$ and Fundação da Universidade Federal do Paraná (FUNPAR).

Disclosure: no potential conflict of interest relevant to this article was reported.

\section{REFERENCES}

1. Masson $\mathrm{P}$, Chatonnet $\mathrm{A}$, Lockridge $\mathrm{O}$. Evidence for a single butyrylcholinesterase gene in individuals carrying the $\mathrm{C} 5$ plasma cholinesterase variant (CHE2). FEBS Lett. 1990;262(1):115-8.

2. Chautard-Freire-Maia EA, Primo-Parmo SL, Picheth G, Lourenço MA, Vieira MM. The C5 isozyme of serum cholinesterase and adult weight. Hum Hered. 1991;41(5):330-9.

3. Harris H. The principles of human biochemical genetics. Amsterdam, Elsevier/North-Holland Biomedical; 1980.

4. Alcântara VM, Oliveira LC, Réa RR, Suplicy HL, Chautard-FreireMaia EA. Butyrylcholinesterase and obesity in individuals with the CHE2 C5+ and CHE2 C5- phenotypes. Int J Obes Relat Metab Disor. 2003;27(12):1557-64.

5. Souza RL, Furtado L, Diniz AC, Silva AC, Kaiss J, Petzl-Erler ML, et al. Studies on a heterologous complex formed by human butyrylcholinesterase. Biochem Genet. 2003;41(5-6):141-50.

6. Antopol W, Tuchman L, Schifrin A. Cholinesterase activity of human sera with special reference to hyperthyroidism. Proc Soc Exp Biol Med. 1937;36:46-50.

7. Alcântara VM, Chautard-Freire-Maia EA, Scartezin M, Cerci MS, Braun-Prado K, Picheth G. Butyrylcholinesterase activity and risk factors for coronary artery disease. Scand J Clin Lab Invest. 2002;62(5):399-404.

8. Cucuianu M, PopescuTA, Opincaru A, Haragus S. Serum pseudocholinesterase and ceruloplasmin in various types of hyperlipoproteinemia. Clin Chem Acta. 1975;59(1):19-27.
9. Crook $M$, Haq $M$, Tutt P. Serum lipids, acute phase proteins and serum cholinesterase in normal subjects. Scand J Clin Lab Invest. 1994;54(8):601-3.

10. Magarian EO, Dietz AJ. Correlation of cholinesterase with serum lipids and lipoproteins. J Clin Pharmacol. 1987;27(10):819-20.

11. Simpson NE. Factors influencing cholinesterase activity in a Brazilian population. Am J Hum Genet. 1966;18(3):243-52.

12. Kutty KM, Jain R, Huang S, Kean K. Serum pseudocholinesterase: high density lipoprotein cholesterol ratio as an index of risk for cardiovascular disease. Clin Chim Acta. 1981;115(1):55-61.

13. Alcântara VM, Oliveira LC, Réa RR, Suplicy HL, Chautard-FreireMaia EA. Butyrylcholinesterase activity and metabolic syndrome in obese patients. Clin Chem Lab Med. 2005;43(3):285-8.

14. Report of the Expert Committee on the Diagnosis and Classification of Diabetes Mellitus. Diabetes Care. 2003;26:Suppl 1:S5-S20.

15. Bierman EL. George Lyman Duff Memorial Lecture. Atherogenesis in diabetes. Arterioscler Thromb Vasc Biol. 1992;12:647-56.

16. Brochu M, Poehlman ET, Ades PA. Obesity, body fat distribution, and coronary artery disease. J Cardiopulm Rehabil. 2000;20(2):96-108.

17. Nagaretani $H$, Nakamura $T$, Funahashi $T$, Kotani $K$, Miyanaga $M$, Tokunaga $K$, et al. Visceral fat is a major contributor for multiple risk factors clustering in Japanese men with impaired glucose tolerance. Diabetes Care. 2001;24(12):2127-33.

18. Pascot A, Despres JP, Lemieux I, Bergeron J, Nadeau A, Prud'homme D, et al. Contribution of visceral obesity to the deterioration of the metabolic risk profile in men with impaired glucose intolerance. Diabetologia. 2000;43:1126-35.

19. Colditz GA, WillettWC, Stampfer MJ, Manson JE, Hennekens $\mathrm{CH}$, Arky RA, et al. Weight as a risk factor for clinical diabetes in women. Am J Epidemiol. 1990;132(3):501-13.

20. Maison P, Byrne CD, Hales CN, Day NE, Wareham NJ. Do different dimensions of the metabolic syndrome change together over time? Evidence supporting obesity as the central feature. Diabetes Care. 2001;24(10):1758-63.

21. Abbott CA, Mackness MI, Kumar S, Olukoga AO, Gordon C, Arrol $S$ et al. Relationships between serum butyrylcholinesterase activity, hypertriglyceridaemia and insulin sensitivity in diabetes mellitus. Clin Sci. 1993;85:77-81.

22. Taskinen MR. Quantitative and qualitative lipoprotein abnormalities in diabetes mellitus. Diabetes. 1992;41: Suppl 2:12-7.

23. Steinberg D, Gotto AM Jr. Preventing coronary artery disease by lowering cholesterol levels: fifty years from bench to bedside. JAMA. 1999;282(21):2043-50.

24. Frohlich J, Dobiasova M. Fractional esterification rate of cholesterol and ratio of triglycerides to HDL-cholesterol are powerful predictors of positive findings on coronary angiography. Clin Chem. 2003;49(11):1873-80.

25. Dietz AA, Rubinstein HM, Lubrano T. Colorimetric determination of serum cholinesterase and its genetic variants by the propionylthiocholine-dithiobis (nitrobenzoic acid) procedure. Clin Chem. 1973;19(11):1309-13.

26. Evans RT, Wroe J. Is serum cholinesterase activity a predictor of succinylcholine sensitivity? An assessment of four methods. Clin Chem. 1978;24(10):1762-66.

27. Van Ros $G$, Vervoort T. Frequencies of the atypical and $C 5$ variants of serum cholinesterase in Zairians and Belgians. Detection of the C5 variant by agar gel electrophoresis with an acid buffer. Ann Soc Belg MedTrop. 1973;53:633-44.

28. Kodak Digital. Corel Photo Paint 9. NewYork, 1995-1997, 1 CD-ROM.

29. Kodak 1D. Image Analyses Software for Windows. New York, v. 3.5, 1994-2000, 1 CD-ROM.

30. Statsoft. Microsoft, Inc. Statistica for Windows. Tulsa, 1996. 1CD-ROM.

31. Matthews DR, Hosker JP, Rudenski AS, Naylor BA, Treacher DF, Turner RC. Homeostasis model assessment: insulin resistance 
and beta-cell function from fasting plasma glucose and insulin concentrations in man. Diabetologia. 1985;28(7):412-9.

32. Alcântara VM, Rodrigues, LC, Oliveira, LC, Chautard-Freire-Maia EA. Association of the CHE2 locus with body mass index and butyrylcholinesterase activity. Hum Biol. 2001;73:587-95.

33. Propert DN, Brackenridge CJ. The relation of sex, age, smoking status, birth rank and parental ages to pseudocholinesterase activity and phenotypes in a sample of Australian Caucasian adults. Hum Genet. 1976;32(2):181-8.

34. Alcântara VM, Rodrigues LC, Oliveira LC, Chautard-Freire-Maia EA.The variable expression of the $\mathrm{C} 4 / 5$ complex of human butyrylcholinesterase and body mass index. Hum Biol. 2003;75(1):47-55.

35. Sidell FR, Kaminskis A. Influence of age, sex, and oral contraceptives on human blood cholinesterase activity. Clin Chem. 1975;21(10):1393-5.

36. Shnider SM. Serum cholinesterase activity during pregnancy, labor and the puerperium. Anesthesiology. 1965;26:335-9.

37. Robertson GS. Serum cholinesterase deficiency. II: pregnancy. $\mathrm{Br}$ J Anaesth. 1966;38(5):361-9.

38. Kissebah AH, Vydelingum N, Murray R, Evans DJ, Hartz AJ, Kalkhoff $\mathrm{RK}$, et al. Relation of body fat distribution to metabolic complications of obesity. J Clin Endocrinol Metab. 1982;54(2):254-60.
39. Ghiringhello MT, Vieira JG, Tachibana TT, Ferrer C, Maciel RM, Amioka PH, et al. Distribution of HOMA-IR in Brazilian subjects with different body mass indexes. Arq Bras Endocrinol Metab. 2006;50(3):573-4.

40. Cakan N, Ellis DA, Templin T, Frey M, Naar-King S. The effects of weight status on treatment outcomes in a randomized clinical trial of multisystemic therapy for adolescents with type 1 diabetes and chronically poor metabolic control. Pediatr Diabetes. 2007;8(4):206-13.

41. Xu P, Cuthbertson D, Greenbaum C, Palmer JP, Krischer JP. Role of insulin resistance in predicting progression to type 1 diabetes. Diabetes Care. 2007;30(9):2314-20.

42. Kissebah $\mathrm{AH}$. Insulin resistance in visceral obesity. Int $\mathrm{J}$ Obes. 1991;15 Suppl 2:109-15.

43. Zavaroni I, Bonini L, Fantuzzi M, Dall'Aglio E, Passeri M, Reaven GM. Hyperinsulinaemia, obesity, and syndrome X. J Intern Med. 1994;235(5):51-6.

44. World Health Organization. BMI classification. [Homepage on the internet] [cited 2009 sep 9]. Available from: http://www.who.int/ bmi/index.jsp?introPage=intro_3.html

45. Iwasaki T, Yoneda M, Nakajima A, Terauchi Y. Serum butyrylcholinesterase is strongly associated with adiposity, the serum lipid profile and insulin resistance. Intern Med. 2007;46(19):1633-9. 